\title{
KIT Exon 18 Mutation
}

National Cancer Institute

\section{Source}

National Cancer Institute. KIT Exon 18 Mutation. NCI Thesaurus. Code C153251.

A change in the nucleotide sequence in exon 18 of the KIT gene. 